\title{
Perception and Level of Awareness of Climate Change among Adult Learners on Attendance and Performance in Literacy Centres, Ondo State, Nigeria
}

\section{| Francis O. Olaniyi |}

\author{
Department of Adult \\ Education, Faculty of \\ Education, Adekunle Ajasin \\ University, Akungba-Akoko, \\ Ondo State, Nigeria
}

drfrancisolaniyi@gmail.com

\begin{abstract}
This study investigated theperception and awareness of climate change among adult learners on attendance and performance in literacy centres in Ondo State, Nigeria. Five research questions were generated for the study. The descriptive research design of the survey type was used for the study involving a population of adult learners in literacy centres in Ondo State, Nigeria. Purposive random sampling technique was used to select a sample size of 100 participants drawn from the entire population of adult learners in literacy centres of Ondo State, Nigeria. A selfconstructed questionnaire was used as an instrument for the study. Data collected were analysed using descriptive statistics of frequency counts, percentage and mean deviation were used to answer the research questions raised for the study. Findings revealed that the level of awareness on climate change among adult learners on attendance and performance is very high because they were already aware of climate change and its effects on human existence. Also, adult learners do not perceive climate change as the work of nature alone but as well as the effects of activities of man on the environment. Findings also revealed that that several factors like deforestation, bush burning, air pollution and other man's activities on the environment such as mining, science and technology among others are the causes of climate change. It is therefore recommended that, information should be disseminated to the people on proper management of the environment. Government should not relent in conducting house to house orientation on how to conserve the environment from the effects of climate change.
\end{abstract}

\section{KEYWORDS}

Perception; awareness; climate change; adult learners;

attendance; performance

\section{INTRODUCTION}

Climate change is arguably one of the greatest issues facing our society today, and peoples' capacities to 'adapt' to climate change have become central to policy responses globally. Despite this, climate change education and the general dissemination of climate change knowledge have traditionally been of low priority. However, with climate change adaptation being increasingly considered crucial within the broader context of sustainable development, improved climate change awareness and education is one factor that is being seen as a facilitative tool to improve adaptive capacity in society as a whole (UNFCCC, 2014). 
The United States Environmental Protection Agency (USEPA, 2014) stated that Climate change refers to any significant change in the measures of climate lasting for an extended period of time. In other words, climate change includes major changes in temperature, precipitation, or wind patterns, among other effects, that occur over several decades or longer. Knutson (2011) referred to climate change research as a big endeavour because of its involvement with the entire planet and everything that affects their survival, global climate change impacts on human and natural systems are predicted to be severe, as evidence of climate change and its impact continues to be amassed. The impacts of climate change according to the United States Environmental Protection Agency include warming temperatures, changes in precipitation, and increases in the frequency or intensity of some extreme weather events, and rising sea levels. These impacts threaten human health by affecting the food we eat, the water we drink, the air we breathe, and the weather we experience (USEPA, 2014). The severity of these health risks will depend on the ability of public health and safety systems to address or prepare for these changing threats, as well as factors such as an individual's behaviour, age, gender, and economic status. Impacts will vary based on a where a person lives, how sensitive they are to health threats, how much they are exposed to climate change impacts, and how well they and their community are able to adapt to change (USEPA, 2014).

The challenges posed by climate change crises constitute major threat to sustainable development. The concern of sustainable development relates to the need to face and save the future in order to keep and safeguard the interests of the coming generations. Climate change influences key natural and human living conditions and thereby also the basis for social and economic development while on the other hand society's priorities on sustainable development influence both the greenhouse gases (GHG) emissions that are causing climate change and vulnerability. The four most important greenhouse gases are carbon dioxide, methane, nitrous oxide and fluorinated gases (Agboola,Omowunmi, Emmanuel, Michael, 2016). Human activities are responsible for almost all of the increase in greenhouse gases in the262atmosphere over the last one hundred and fifty (150) years (IPCC, 2007). Being curious about the environment and its sustenance is not science but the thirst for knowledge (Agboola, Omowunmi, Emmanuel and Michael, 2016). All humans reserve the right to be curious about discovering as much as possible about our planet, and studying its inhabitants. Therefore, knowledge and awareness of climate change and associated concepts is an intellectual activity to be possessed by all regardless of the educational bias or background, sex, age, or level of education. As climate changes, everything changes from the natural habitat of wildlife to the culture and sustainable of a region. Some of the effects of climate change are sea level rise, changes in rainfall patterns, water scarcity and adverse health effects from warmer temperature (Marty \&Yokochi, 2006). Climate change has a cumulative effect on natural resources and the balance of nature and its effects are already visible in the country (Agboola, Omowunmi, Emmanuel and Michael, 2016).

This study seeks to investigate and assess the perception and level of awareness of climate change among adult learners on attendance and performance in literacy centres in Ondo State, Nigeria. Therefore the specific objectives of this study are to:

1. as certain the level of climate change awareness among adult learners.

2. determine adult learner's perception on climate change, attendance and performance.

3. examine the knowledge of adult learners about the causes of climate change.

4. investigate adult learners' sources of knowledge and information on climate change.

5. recommend ways through which information about climate change can be easily disseminated among adult learners. 


\section{Research Questions}

1. What is the level of awareness on climate change among adult learners?

2. How do adult learners perceive climate change on attendance and performance?

3. How knowledgeable are adult learners about the causes of climate change?

4. How accessible are adult learners to sources of information on climate change?

5. What are the ways through which climate change education or information can be easily disseminated to adult learners?

\section{LITERATURE REVIEW}

\section{Concept of Climate System}

Climate is traditionally defined as the description in terms of the mean and variability of relevant atmospheric variables such as temperature, precipitation and wind. Climate can thus be viewed as a synthesis or aggregate of weather. This implies that the portrayal of the climate in a particular region must contain an analysis of mean conditions, of the seasonal cycle, of the probability of extremes such as severe frost and storms. Following the World Meteorological Organisation (WMO), 30 years is the classical period for performing the statistics used to define climate. This is well adapted for studying recent decades since it requires a reasonable amount of data while still providing a good sample of the different types of weather that can occur in a particular area. However, when analysing the most distant past, such as the last glacial maximum around 20,000 years ago, climatologists are often interested in variables characteristic of longer time intervals. As a consequence, the 30-year period proposed by the WMO should be considered more as an indicator than a norm that must be followed in all cases. This definition of the climate as representative of conditions over several decades should, of course, not mask the fact that climate can change rapidly. Nevertheless, a substantial time interval is needed to observe a difference in climate between any two periods. We must also take into account the fact that the state of the atmosphere used in the definition of the climate given above is influenced by numerous processes involving not only the atmosphere but also the ocean, the sea ice, the vegetation, and so on (IPCC, 2007). Climate is thus now more and more frequently defined in a wider sense as the statistical description of the climate system. This includes the analysis of the behavior of its five major components: the atmosphere (the gaseous envelope surrounding the Earth), the hydrosphere (liquid water, such as the ocean, lakes, underground water, and so on), the cryosphere (solid water, such as the sea ice, glaciers, ice sheets), the land surface and the biosphere (all the living organisms), and of the interactions between them (IPCC, 2007).

\section{Concept of Climate Change}

NASA, (2012) defines climate change as; "a broad range of global phenomena created predominantly by burning fossil fuels, which add heat-trapping gases to Earth's atmosphere. These phenomena include the increased temperature trends described by global warming, but also encompass changes such as sea level rise; ice mass loss in Greenland, Antarctica, the Arctic and mountain glaciers worldwide; shifts in flower/plant blooming; and extreme weather events."

Idowu, Ayoola, Opele, Ikenweiwei, (2011) refers to climate change as some observable variations in the climate system that are attributable to human (anthropogenic) activities, especially those that alter the atmospheric composition of the earth and ultimately lead to global warming. They further explained that global warming is closely associated with 
Climate change especially as co-traveler in the interplay of the equilibrium between the natural and man-made components of the Green House Gases (GHGs) that have been eminently adjudged globally as the culprit for the warming of the earth's atmosphere and ocean. Global warming is the term used to describe the gradual increase in the average temperature of earth's atmosphere and its ocean (Idowu, Ayoola, Opele, Ikenweiwei, 2011).

Global warming is caused by increase in the emission of GHGs through the burning of fossil fuels (oils, natural gas and coal), burning of wood, wood product and solid wastes, raising of livestock and the decomposition of organic wastes in solid waste landfills; combustion of solid wastes and fossil fuels in industrial and agricultural activities; bush burning; deforestation. All these human (anthropogenic) activities contribute to alter the balance of the equilibrium between the natural GHGs (water vapor, carbon dioxide, methane and nitrous oxide) and the man-made GHGs (sulfur hexane fluoride (SF6); hydrofluorocarbons (HFCs); and per fluorocarbons (PFCs) in earth's atmosphere thus promoting the warming of both the atmosphere and the oceans since they are heat-trapping (Idowu, Ayoola, Opele, Ikenweiwei, 2011). The level of these GHGs has increased beyond natural level (Nest, 2004). There is a scientific consensus that the average temperature of earth has risen between 0.4 and 0.8 degree centigrade in the last 100 years (IPCC, 2007). The increased volume of carbondioxide and other GHGs released from burning of fossil fuels, deforestation, agriculture and other human activities are source of global warming that have occurred in the last 50 years (IPCC, 2007). Awosika (1992) inIdowu, Ayoola, Opele, Ikenweiwei, (2011) stressed that GHGs are good absorbers of heat radiation coming from earth's surface acting like a blanket over its atmosphere, keeping it warmer than it would be.

Climate Change has been undoubtedly the most illustrious environmental issue since late 20th century. But neither the discourse merely emerged during the time, nor it was problematised in the same way since its onset, the history of Climate Change discourse reveals that from a purely scientific concern it has turned into a public agenda that is nowadays more inclined to be development problem.

\section{Causes and Effects of Climate and Environmental Changes}

Man cannot naturally be detached from his environment. From time to time, changes in climate and environmental conditions occur as a result of natural and human factors. Obviously, the natural factors are almost beyond human control. But, the human factors are to a very large extent under human control, Such human factors include, air, water and land pollutions, production of greenhouse gases, deforestation, desertification, emission of carbon dioxide, carbon monoxide and other harmful gases. Natural factors include, volcanic eruption, ocean variations, solar variations, Plate Tectonics, Thermohaline circulations, (Nwankwoala, 2015).

In a broad sense, climate and environmental changes is the after mat of so many human activities and some natural occurrences. Some natural causes of climate change are referred to as "climate forcing" or "forcing mechanisms". Changes in the state of this system can occur externally (from extraterrestrial systems) or internally (from ocean, atmosphere and land systems), through any one of the described components. For example, an external change may involve a variation in the Sun's output which would externally vary the amount of solar radiation received by the Earth's atmosphere and surface. Internal variations in the Earth's climate system may be caused by changes in the concentrations of atmospheric gases, mountain building, and volcanic activities (Lopes, and Mckay, 2020). 


\section{Climate Change Education (CCE)}

Climate Change Education (CCE) is learning geared towards helping people address and develop effective responses to climate change. It helps learners understand the causes and consequences of climate change, prepares them to live with the impacts of climate change and empowers learners to take appropriate actions to adopt more sustainable lifestyles (UNESCO, 2015). Climate change education is about learning in the face of risk, uncertainty and rapid change. Humans have never before been in the situation now confronting the planet (IPCC, 2014; WHO, 2020).

Climate change education throughout formal education systems can be one of the most important and effective means of developing capacities for addressing the climate crisis. This is due to multiplier effects, where families and communities benefit when individuals share what they have learnt especially in relation to adaptation and mitigation, Climate change education explores mitigation and adaptation at both the local and global level and the interrelationships between these levels (Kagawa \& Selby, 2010).

We have to respond through collaborative problem-solving and innovation across multiple dimensions of environmental, social, economic, political and educational institutions and systems. Innovation depends on being able to learn collaboratively, adaptively, productively and quickly, as well as to act across different and often vast scales of both space and time. Therefore, climate change education demands a focus on the kind of learning, critical and creative thinking and capacity building that will enable youth to engage with the information, inquire, understand, ask critical questions and take what they determine are appropriate actions to respond to climate change. Mitigation efforts, however, will not be enough to respond to climate change, so individuals and communities will also need to adapt to future impacts that are unlikely to be avoided. Preparedness for current and potential consequences of climate change is progressively being recognised as essential. As we do not fully understand the implications of a future shaped by climate change, adaptation education is considered necessary to the lower risk and vulnerability and build adaptive capacity and resilience (Krasny \& Dubois, 2016). The unpredictable nature of climate change requires an approach to learning that is flexible and that builds capacity for responding to specific hazards as well as for reducing general vulnerabilities (Anderson, 2012).

Climate Change Education helps policy makers understand the urgency and importance of putting mechanisms into place to combat climate change on a national and global scale. Communities learn about how climate change will affect them, what they can do to protect themselves from negative consequences, and how they can reduce their own climate footprint. In particular, Climate Change Education helps increase the resilience of already vulnerable communities who are the most likely to be adversely affected by climate change (UNESCO, 2015)

The UNESCO Climate Change Education for Sustainable Development programme (CCESD) was established in 2010 which aims to help people understand climate change by expanding climate change education activities in non-formal education through the media, networking and partnerships. It is grounded in the holistic approach of Education for Sustainable Development (ESD) which incorporates key sustainable development issues such as climate change, disaster risk reduction and others into education, in a way that addresses the interdependence of environmental sustainability, economic viability and social justice. It promotes participatory teaching and learning methods that motivate and empower learners to change their behaviour and take action for sustainable development.

The programme seeks to help people understand the impact of global warming today and increase 'climate literacy', especially among young people, and aims to make 
education a more central part of the international response to climate change. UNESCO works with national governments to integrate Climate Change Education into national curricula and to develop innovative teaching and learning approaches for doing so. Climate Change Education for Sustainable Development (CCESD), therefore, has a central role to play in helping the general public and especially the next generations understand and relate to the issues, make lifestyle changes to reduce greenhouse gas emissions, and adapt to the changing local conditions. While CCESD at all levels and in both formal and non-formal settings is needed, instilling climate change awareness and understanding at a young age is ultimately the best way to change behaviours and attitudes. To ensure relevance and uptake, climate change education for sustainable development should be oriented according to the local context and prioritize passing traditional knowledge and practices to learners (UNESCO, 2015).

\section{RESEARCH METHODS}

\section{Research Design}

The study adopted a descriptive survey design which requires the opinion of respondents to respond to some variables. Data was collected and analysed based on specific population, in which results represented the entire population.

\section{Population}

The population of the study comprised of all adult learners in adult literacy centres in Ondo State, Nigeria.

\section{Sample}

The sample constituted one hundred (100) adult learners purposively selected from adult literacy centres in Ondo State, Nigeria, using purposive random sampling technique.

\section{Instrument}

The instrument was a structured questionnaire developed for this study. It was in line with the objectives of the studyas well as the research questions. A face-to-face system of distribution was used.

\section{Data Collection and Analysis}

The data collected were analysed using descriptive statistics of frequency counts and percentages, as well as mean scores; decision were based on the mean score of 2.5 and above were accepted while mean score below 2.5 were rejected. Results obtained are presented according to research questions formulated for the study. One hundred (100) copies of the questionnaire were administered and anlysed.

\section{RESULTS AND DISCUSSION}

Research Question One:What is the level of awareness on climate change among adult learners?

Table 1. Descriptive analysis of level of awareness of climate change

\begin{tabular}{|c|l|l|l|l|l|l|l|}
\hline S/N & \multicolumn{1}{|c|}{ Items } & $\begin{array}{l}\text { SA } \\
(\mathbf{\%})\end{array}$ & $\begin{array}{l}\text { A } \\
(\mathbf{\%})\end{array}$ & $\begin{array}{l}\mathbf{D} \\
(\mathbf{\%})\end{array}$ & $\begin{array}{l}\text { SD } \\
(\mathbf{\%})\end{array}$ & Mean & Decision \\
\hline 6 & $\begin{array}{l}\text { I am aware that climate } \\
\text { change is real. }\end{array}$ & $\begin{array}{l}55 \\
(55.0)\end{array}$ & $\begin{array}{l}40 \\
(40.0)\end{array}$ & $\begin{array}{l}5 \\
(5.0)\end{array}$ & - & 3.5 & Accepted \\
\hline 7 & $\begin{array}{l}\text { I do not believe in climate } \\
\text { change. }\end{array}$ & $\begin{array}{l}10 \\
(10.0)\end{array}$ & $\begin{array}{l}10 \\
(10.0)\end{array}$ & $\begin{array}{l}40 \\
(40.0)\end{array}$ & $\begin{array}{l}40 \\
(40.0)\end{array}$ & 1.9 & Rejected \\
\hline
\end{tabular}




\begin{tabular}{|c|c|c|c|c|c|c|c|}
\hline 8 & $\begin{array}{l}\text { The orientation I have } \\
\text { about climate change is } \\
\text { low. }\end{array}$ & $\begin{array}{l}25 \\
(25.0)\end{array}$ & $\begin{array}{l}20 \\
(20.0)\end{array}$ & $\begin{array}{l}35 \\
(35.0)\end{array}$ & $\begin{array}{l}20 \\
(20.0)\end{array}$ & 2.5 & Accepted \\
\hline 9 & $\begin{array}{l}\text { I am hearing about } \\
\text { climate change for the } \\
\text { first time. }\end{array}$ & $\begin{array}{l}20 \\
(20.0)\end{array}$ & $\begin{array}{l}55 \\
(55.0)\end{array}$ & - & $\begin{array}{l}25 \\
(25.0)\end{array}$ & 2.15 & Rejected \\
\hline & Grand Mean & & & & & 2.51 & Accepted \\
\hline
\end{tabular}

Source: Field Survey, 2020

From Table 1 above, on item 6,95(95.0\%) of the respondents agreed that they are aware that climate change is real, while $5(5.0 \%)$ of the respondents disagreed with the statement, with the mean of 3.5, this implies that the respondents have been aware about climate change before. On item 7, 20(20.0\%) of the respondents agreed that they do not believe in climate change while, $80(80.0 \%)$ of the respondents disagreed with the statement, with the mean of 1.9, this reveals that the respondents do not have believe in climate change. On item $8,45(45.0 \%)$ of the respondents agreed that the orientation they have about climate change is low while, 55(55.0\%) of the respondents disagreed with the statement, with the mean of 2.5, this indicates that the orientation of the respondents have on what climate change is all about is very low. On item $9,75(75.0 \%)$ of the respondents agreed that they are hearing about climate change for the first time while, 25(25.0\%) of the respondents disagreed with the statement, with the mean of 2.15, this implies that this was not the first time the respondents would hear about climate change.

In response to research question one with the Grand Mean of 2.51; this reveals that the level of awareness on climate change among adult learners is very high because they were already aware of climate change and its effects on human existence.

Research Question Two: How do adult learners perceive climate change on attendance and performance?

Table 2. Descriptive analysis of perception of climate change on attendance and

\begin{tabular}{|c|c|c|c|c|c|c|c|}
\hline $\mathbf{S} / \mathbf{N}$ & Items & $\begin{array}{l}\text { SA } \\
(\%)\end{array}$ & $\begin{array}{l}\mathrm{A} \\
(\%)\end{array}$ & $\begin{array}{l}D \\
(\%)\end{array}$ & $\begin{array}{l}\text { SD } \\
(\%)\end{array}$ & Mean & Decision \\
\hline 10 & $\begin{array}{l}\text { I believe climate change } \\
\text { is a myth. }\end{array}$ & $\begin{array}{l}20 \\
(20.0)\end{array}$ & $\begin{array}{l}15 \\
(15.0)\end{array}$ & $\begin{array}{l}50 \\
(50.0)\end{array}$ & $\begin{array}{l}15 \\
(15.0)\end{array}$ & 2.4 & Accepted \\
\hline 11 & $\begin{array}{l}\text { I think climate change is } \\
\text { changing because is angry } \\
\text { at us. }\end{array}$ & $\begin{array}{l}10 \\
(10.0)\end{array}$ & $\begin{array}{l}10 \\
(10.0)\end{array}$ & $\begin{array}{l}45 \\
(45.0)\end{array}$ & $\begin{array}{l}35 \\
(35.0)\end{array}$ & 1.95 & Rejected \\
\hline 12 & $\begin{array}{l}\text { I believe that hotness of } \\
\text { weather is due to climate } \\
\text { change. }\end{array}$ & $\begin{array}{l}35 \\
(35.0)\end{array}$ & $\begin{array}{l}45 \\
(45.0)\end{array}$ & $\begin{array}{l}20 \\
(20.0)\end{array}$ & - & 3.15 & Accepted \\
\hline 13 & $\begin{array}{l}\text { I have not heard much } \\
\text { about climate change so I } \\
\text { have no opinion. }\end{array}$ & $\begin{array}{l}5 \\
(5.0)\end{array}$ & $\begin{array}{l}20 \\
(20.0)\end{array}$ & $\begin{array}{l}30 \\
(30.0)\end{array}$ & $\begin{array}{l}45 \\
(45.0)\end{array}$ & 1.83 & Rejected \\
\hline & Grand Mean & & & & & 2.33 & Rejected \\
\hline
\end{tabular}

Source: Field Survey, 2020

From Table 2 above, on item 10, above, 35(35.0\%) of the respondents agreed that they believe climate change is a myth while, $65(65 \%)$ of the respondents disagreed with the statement, with the Mean of 2.4, this implies that the respondents refute the fact that 
climate change is not a myth. On item 11, 20(20.0\%) of the respondents agreed that they think climate change is changing because is angry at them while, $80(80 \%)$ of the respondents disagreed with the statement, with the Mean of 1.95, it indicates that climate does not change because it is angry at them but due to man activities on the environment. On item $12,80(80 \%)$ of the respondents agreed that they believe that hotness of weather is due to climate change while, 20(20.0\%) of the respondents disagreed with the statement, with the Mean of 3.15, this revealed that the hotness of the weather is due to the change in climatic condition. On item $13,25(25.0 \%)$ of the respondents agreed that they have not heard much about climate change so they have no opinion while, $75(75.0 \%)$ of the respondents disagreed with the statement, with the Mean of 1.83, this indicates that adult learners have heard much about climate therefore they have opinion.

In response to research question 2, with the Grand Mean of 2.33, it could be affirmed that adult learners do not believe that climate change is a myth nor do they think that climate change is changing because is angry at them therefore adult learners do not perceive climate change as the work of nature alone but as well as due to the activities of man on the environment.

Research Question Three: How knowledgeable are adult learners about the causes of climate change?

Table 3. Descriptive analysis of knowledge about the causes of climate change

\begin{tabular}{|c|c|c|c|c|c|c|c|}
\hline $\mathbf{S} / \mathbf{N}$ & Items & $\begin{array}{l}\text { SA } \\
(\%)\end{array}$ & $\begin{array}{l}A \\
(\%)\end{array}$ & $\begin{array}{l}\mathrm{D} \\
(\%)\end{array}$ & $\begin{array}{l}\text { SD } \\
(\%)\end{array}$ & Mean & Decision \\
\hline 14 & $\begin{array}{l}\text { I believe climate change } \\
\text { is caused by the } \\
\text { activities of man. }\end{array}$ & $\begin{array}{l}50 \\
(50.0)\end{array}$ & $\begin{array}{l}45 \\
(45.0)\end{array}$ & $\begin{array}{l}5 \\
(5.0)\end{array}$ & - & 3.45 & Accepted \\
\hline 15 & $\begin{array}{l}\text { Bush burning contributes } \\
\text { to climate change. }\end{array}$ & $\begin{array}{l}65 \\
(65.0)\end{array}$ & $\begin{array}{l}25 \\
(25.0)\end{array}$ & $\begin{array}{l}5 \\
(5.0)\end{array}$ & $\begin{array}{l}5 \\
(5.0)\end{array}$ & 3.5 & Accepted \\
\hline 16 & $\begin{array}{l}\text { Deforestation is another } \\
\text { factor causing climate } \\
\text { change. }\end{array}$ & $\begin{array}{l}55 \\
(55.0)\end{array}$ & $\begin{array}{l}40 \\
(40.0)\end{array}$ & - & $\begin{array}{l}5 \\
(5.0)\end{array}$ & 3.45 & Accepted \\
\hline 17 & $\begin{array}{l}\text { Air pollution contributes } \\
\text { to climate change. }\end{array}$ & $\begin{array}{l}60 \\
(60.0)\end{array}$ & $\begin{array}{l}30 \\
(30.0)\end{array}$ & $\begin{array}{l}10 \\
(10.0)\end{array}$ & - & 3.5 & Accepted \\
\hline & Grand Mean & & & & & 3.48 & Accepted \\
\hline
\end{tabular}

Source: Field Survey, 2020

From Table 3 above, on item 14, 95(95.0\%) of the respondents agreed that they believe climate change is caused by the activities of man while, $5(5.0 \%)$ of the respondents disagreed with the statement, with the Mean of 3.45, this indicates that climate change is caused by the activities of man such as mining, the advent of science and technology among others. On item 15, 90(90.0\%) of the respondents agreed that bush burning contributes to climate change while, $10(10.0 \%)$ of the respondents disagreed with the statement, with the Mean of 3.5, it could be deduced that man's activities on the environment like bush burning adverse effect on climate. On item 16, 95(95.5\%) of the respondents agreed that deforestation is another factor causing climate change while, $5(5.0 \%)$ of the respondents disagreed with the statement, with the Mean of 3.45, this implies that deforestation is another factor causing climate change. On item 17, 90(90.0\%) of the respondents agreed that air pollution contributes to climate change while, $10(10.0 \%)$ of the respondents disagreed with the statement, with the Mean of 3.5, this implied that air pollution contributes to climate change. 
In response to research question 3, with the Gran Mean of 3.48, it could be affirmed that adult learners are more knowledgeable about the causes of climate change. According to their response it could be deduced that several factors like deforestation, bush burning, air pollution and other man's activities on the environment such as mining, science and technology among others are the causes of climate change.

Research Question Four: How accessible are adult learners to sources of information on climate change?

Table 4. Descriptive analysis of sources of information on climate change

\begin{tabular}{|c|l|l|l|l|l|l|l|}
\hline S/N & \multicolumn{1}{|c|}{ Items } & $\begin{array}{l}\text { SA } \\
(\mathbf{\%})\end{array}$ & $\begin{array}{l}\text { A } \\
(\mathbf{\%})\end{array}$ & $\begin{array}{l}\mathbf{D} \\
(\mathbf{\%})\end{array}$ & $\begin{array}{l}\text { SD } \\
(\mathbf{\%})\end{array}$ & Mean & Decision \\
\hline 18 & $\begin{array}{l}\text { I usually listen to radio } \\
\text { programmes on climate } \\
\text { change. }\end{array}$ & $\begin{array}{l}15 \\
(15.0)\end{array}$ & $\begin{array}{l}45 \\
(45.0)\end{array}$ & $\begin{array}{l}25 \\
(25.0)\end{array}$ & $\begin{array}{l}15 \\
(15.0)\end{array}$ & 2.6 & Accepted \\
\hline 19 & $\begin{array}{l}\text { I once attended a public } \\
\text { seminar on climate } \\
\text { change. }\end{array}$ & $\begin{array}{l}35 \\
(35.0)\end{array}$ & $\begin{array}{l}10 \\
(10.0)\end{array}$ & $\begin{array}{l}10 \\
(10.0)\end{array}$ & $\begin{array}{l}45 \\
(45.0)\end{array}$ & 2.35 & Rejected \\
\hline 20 & $\begin{array}{l}\text { I only read about climate } \\
\text { change on newspaper. }\end{array}$ & $\begin{array}{l}10 \\
(10.0)\end{array}$ & $\begin{array}{l}55 \\
(55.0)\end{array}$ & $\begin{array}{l}30 \\
(30.0)\end{array}$ & $\begin{array}{l}5 \\
(5.0)\end{array}$ & 2.7 & Accepted \\
\hline 21 & $\begin{array}{l}\text { They teach about climate } \\
\text { change in my adult } \\
\text { literacy centre. }\end{array}$ & $\begin{array}{l}35 \\
(35.0)\end{array}$ & $\begin{array}{l}45 \\
(45.0)\end{array}$ & $\begin{array}{l}5 \\
(5.0)\end{array}$ & $\begin{array}{l}15 \\
(15.0)\end{array}$ & 3.0 & Accepted \\
\hline & \multicolumn{2}{|c|}{ Grand Mean } & & & & $\mathbf{2 . 6 6}$ & Accepted \\
\hline
\end{tabular}

Source: Field Survey, 2020

From Table 4 above, on item 18,60(60.0\%) of the respondents agreed that they usually listen to radio programmes on climate change while, $40(40.0 \%)$ of the respondents disagreed with the statement, with the Mean of 2.6, this indicates that adult learners usually listen to climate related programmes on radio. On item 19,45(45.0\%) of the respondents agreed with the statement while, 55(55.0\%) of the respondents disagreed that they once attended a public seminar on climate change, with the Mean of 2.35, this implies that majority of adult learners does not attend seminars on climate change. On item 20, $65(65.0 \%)$ of the respondents agreed that they only read about climate change on newspaper while, $35(35.0 \%)$ of the respondents disagreed with the statement, with the Mean of 2.7, it reveals that the most common source of information on climate change for the adult learners is through newspaper. On item $21,80(80.0 \%)$ of the respondents agreed that they teach about climate change in their adult literacy centres while 20(20.0\%) of the respondents disagreed with the statement, with the Mean of 3.0, this implies that in most of the adult literacy centres, climate change is always being taught.

In response to research question 4, with the Grand Mean of 2.66, it is affirmed that adult learners have access to information on climate change in several ways which are; through radio programme, newspapers, seminars, magazines, television programmes, etc. which always enrich them with the current or trending changes in climate change.

Research Question Five: What are the ways through which climate change education or information can be easily disseminated to adult learners? 
Table 5. Descriptive analysis of easy ways of disseminating climate change information

\begin{tabular}{|l|l|l|l|l|l|l|l|}
\hline S/N & \multicolumn{1}{|c|}{ Items } & $\begin{array}{l}\text { SA } \\
(\%)\end{array}$ & $\begin{array}{l}\text { A } \\
(\%)\end{array}$ & $\begin{array}{l}\text { D } \\
(\%)\end{array}$ & $\begin{array}{l}\text { SD } \\
(\%)\end{array}$ & Mean & Decision \\
\hline 22 & $\begin{array}{l}\text { I believe many people will } \\
\text { know more about climate } \\
\text { change if a seminar is } \\
\text { organised through } \\
\text { community based } \\
\text { organization. }\end{array}$ & $\begin{array}{l}50 \\
(50.0)\end{array}$ & $\begin{array}{l}40 \\
(40.0)\end{array}$ & - & $\begin{array}{l}10 \\
(10.0)\end{array}$ & 3.3 & Accepted \\
\hline 23 & $\begin{array}{l}\text { I think using indigenous } \\
\text { language can help in } \\
\text { spreading information } \\
\text { about climate change. }\end{array}$ & $\begin{array}{l}30 \\
(30.0)\end{array}$ & $\begin{array}{l}35 \\
(35.0)\end{array}$ & $\begin{array}{l}15 \\
(15.0)\end{array}$ & $\begin{array}{l}20 \\
(20.0)\end{array}$ & 2.75 & Accepted \\
\hline 24 & $\begin{array}{l}\text { There should be } \\
\text { compulsory house to } \\
\text { house orientation about } \\
\text { climate change. }\end{array}$ & $\begin{array}{l}15 \\
(15.0)\end{array}$ & $\begin{array}{l}55 \\
(55.0)\end{array}$ & $\begin{array}{l}10 \\
(10.0)\end{array}$ & $\begin{array}{l}20 \\
(20.0)\end{array}$ & 2.65 & Accepted \\
\hline 25 & $\begin{array}{l}\text { Sensitizing the people by } \\
\text { the town criers can also } \\
\text { help in transmitting } \\
\text { information about climate } \\
\text { change }\end{array}$ & $\begin{array}{l}50 \\
(50.0)\end{array}$ & $\begin{array}{l}40 \\
(40.0)\end{array}$ & $\begin{array}{l}10 \\
(10.0)\end{array}$ & - & 3.4 & Accepted \\
\hline & Grand Mean & & & & & $\mathbf{3 . 0 3}$ & Accepted \\
\hline
\end{tabular}

Source: Field Survey, 2020

From Table 5 above, on item 22, 90(90.0\%) of the respondents agreed that theybelieve many people will know more about climate change if a seminar is organised through community based organization while, $10(10.0 \%)$ of the respondents disagreed with the statement, with the Mean of 3.3, this means that organising seminar through a community based organization will go a long way in making to know more about climate change. On item $23,65(65.0 \%)$ of the respondents agreed that they think using indigenous language can help in spreading information about climate change while, $35(35.0 \%)$ of the respondents disagreed with the statement, with the Mean of 2.75, this means that using indigenous language will go a long way in spreading information about climate change. On item $24,70(70.0 \%)$ of the respondents agreed that there should be compulsory house to house orientation about climate change while, 30(30.0\%) of the respondents disagreed with the statement, with the Mean of 2.65, this implied that embarking on compulsory house to house orientation will help in the dissemination of information about climate change. On item $25,90(90.0 \%)$ of the respondents agree that sensitizing the people by the town criers can also help in transmitting information about climate change while $10(10.0 \%)$ of the respondents disagreed with the statement, with the Mean of 3.4, this means that information about climate change can as well be transmitted through the town criers.

In response to research question 5, with the Grand Mean of 3.03, this revealed that information on climate change could be disseminated to adult learner via different ways like sensitization of the people by the town criers, organising seminars, house to house orientation, etc. could go a long way in educating and spreading of information about climate change. 


\section{Discussion of Findings}

Findings from research question one with the Grand Mean of 2.51revealed that the level of awareness on climate change among adult learners is very high because they were already aware of climate change and its effects on human existence. This result corroborated the findings of UNFCCC, (2014) of the opinion that Climate change is arguably one of the greatest issues facing our society today, however climate change is the catch-all term for the shift in worldwide weather phenomena associated with an increase in global average temperatures, It's real and temperatures have been going up around the world for many decades.

Results from research question two with the Grand Mean of 2.33 affirmedadult learners do not believe that climate change is a myth nor do they think that climate change is changing because is angry at them, therefore adult learners do not perceive climate change as the work of nature alone but due to the activities of man on the environment. This finding is in line with the submission of Idowu, Ayoola, Opele, \&Ikenweiwe (2011) that Climate change and global warming if left unchecked will cause adverse effects on livelihoods in Nigeria, such as crop production, livestock production, fisheries, forestry and post-harvest activities, because the rainfall regimes and patterns will be altered, floods which devastate farmlands would occur, increase in temperature and humidity which increases pest and disease would occur and other natural disasters like floods, ocean and storm surges, which not only damage Nigerians' livelihood but also cause harm to life and property, would occur.

Findings from research question three with the Gran Mean of 3.48 affirmed that adult learners are more knowledgeable about the causes of climate change. According to their response it could be deduced that climate change does not only occur naturally but also with the man's activities of man on the environment such emission of greenhouse gases or land-use change, deforestation, bush burning, air pollution, mining, science and technology among others are the causes of climate change. This result is in agreement with the findings of Nwankwoala, (2015) who opined that obviously, the natural factors are almost beyond human control. But, the human factors are to a very large extent under human control, Such human factors include, air, water and land pollutions, production of greenhouse gases, deforestation, desertification, emission of carbon dioxide, carbon monoxide and other harmful gases. Natural factors include, volcanic eruption, ocean variations, solar variations, Plate Tectonics, Thermohaline circulations.

Results from research question four with the Grand Mean of 2.66 affirmed that adult learners have access to information on climate change in several ways which are; through radio programme, newspapers, seminars, magazines, television programmes, etc. which always enrich them with the current or trending changes in climate change (Field Survey, 2018).

Findings from research question five with the Grand Mean of 3.03 revealed that information on climate change could be disseminated to adult learner via different ways like sensitization of the people by the town criers, organising seminars, house to house orientation, etc. could go a long way in educating and spreading of information about climate change (Field Trip, 2018).

\section{CONCLUSION}

Based on the findings it can be concluded that climate change do occur naturally, but most importantly due to the activities of man on the environment like bush burning, deforestation, pollution, grazing among others are the reasons behind the changes in 
climatic condition. It should be borne in mind that adult learners are really vast in the awareness of climate change as they receive information on climate change through different media. Therefore, adult learners' perception on climate change inOndo State is that climate change has both negative and positive effect on human existence and not as the work of nature alone but also as a result of man's activities.

\section{Recommendations}

Based on the findings, the following suggestions are hereby made:

- Information should be disseminated to the people on proper management of the environment.

- Government should not relent in conducting house to house orientation on how to conserve the environment from the effect of climate change.

- Adult citizens should be mindful of their day-to-day activities on the environment as emission of greenhouse gases or land-use change, duetoresult in external forcing.

- Climate change education (CCE) should be introduced in school curriculum at all levels (primary, secondary, tertiary institutions), and also Adult Education programmes.

\section{REFERENCES}

Agboola, O. S. \& Emmanuel, M. (2016). Awareness of Climate Change and Sustainable

Development among learners from two Selected Universities in Oyo State, Nigeria Institute of Education, Faculty of Education, Obafemi Awolowo University, Ile-Ife 220005, Nigeria. World Journal of Education 6(3), 2016. http://wje.sciedupress.com

Anderson, A. (2012). Climate change education for mitigation and adaptation. Journal of Education for Sustainable Development., 6(2), 191-206.

Idowu, A. A., Ayoola, S. O., Opele, A. I. \& Ikenweiwe, I. B. (2011).Impact of Climate Change in Nigeria. Department of Aquaculture and Fisheries, Management, University of Agriculture, Abeokuta, Ogun State, Department of Marine Sciences, University of Lagos, Akoka, Yaba, Lagos State, Nigeria.

Intergovernmental Panel on Climate Change (IPCC), (2007). Climate Change 2007. Impact, adaptation and vulnerability. Contribution of Working Group II to the Fourth Assessment Report of the IPCC. Parry, M. L., Canziani, O. F., Palutik of, J. P., van der Linden, P. J. \& Hanson, C. E. Cambridge, UK, Cambridge University Press. pp. 976.

Intergovernmental Panel on Climate Change (IPCC) (2014). Climate change 2014: Synthesis Report. Contribution of working groups I, II and III to the Fifth Assessment Report of the Intergovernmental Panel on Climate Change. Geneva: IPCC. https://www.ipcc.ch/report/ar5/syr/.

IPCC (2007). Fourth Assessment Report. Intergovernmental Panel on Climate Change Secretariat. Geneva, Switzerland. http://www.ipcc.ch/

IPCC: Climate Change (2007). The Physical Science Basis. In Solomon, S.D., et al., eds.: Contribution of Working Group I to the Fourth Assessment Report of the Intergovernmental Panel on Climate Change. Cambridge University Press, Cambridge, 2007.

Knutson, T. (2011). Thinking Big on Climate Issues. Oceanic and Atmospheric Research. National Oceanic and Atmospheric Administration. ArticleID/10285. Retrieved from http://research.noaa.gov/InDepth/MeetOurScientists/CurrentScientist/TabId/546/ArtMI D/2688/ArticleID/10285/Knutson-Tom.aspx. Accessed on 08/05/2018. 
Krasny, M. E., \& DuBois, B. (2016). Climate adaptation education: embracing reality or abandoning environmental values. Environmental Education Research, 1-12. Published online 16 June 2016.

Lopes, H., and Mckay, V. (2020). Adult learning and education as a tool to contain pandemics: the COVID-19 experiences https//www.researchgate.net/publication/342287595_Adult_learning_and_education_as _a_tool_to_contain_pandemics_The_COVID-

19_experience/link/5eecd7f192851ce9e7f108e7/download. Retrieved 04/10/2020

Marty, R., \& Yokochi, R. (2006). Water in the early Earth. Reviews in Mineralogy and Geochemistry, 62, 421-450.http://dx.doi.org/10.2138/rmg.2006.62.18

National Aeronautics and Space Administration, NASA, (2012) Climate Change: How do we know? NASA, 2012, http://climate.nasa.gov/evidence

NEST. (2004). Executive Summary of Five Multi-Sector Survey on Nigeria Vulnerability and Adaptation to Climate Change. N.E.S.T. Ibadan, Nigeria.

Nwankwoala, G. (2015). Causes of Climate and Environmental Changes: The need for Environmental-Friendly Education Policy in Nigeria Department of Education Foundation Management, Ignatius Ajuru University of Education, Port Harcourt, Rivers State Nigeria. Journal of Education and Practice 6(30), 2015. ISSN 2222-1735 (Paper) ISSN 2222-288X

UNESCO, (2015). Not Just Hot Air: Putting Climate Change Education into Practice (PDF). Paris, UNESCO. pp. 6, 8, 10, 32, 40, 44, 46, 48, 58. ISBN 978-92-3-1001017.United Nations Educational Scientific and Cultural Organization (UNESCO), \& United Nations Environment Programme (UNEP) (2011). Climate change starters guide book. Paris: UNESCO.

UNFCCC, (2014). Article 6 - Education Training and Public Awareness. United Nations Framework Convention on Climate Change.

World Health Organization (2020). Q\&A on cononaviruses (COVID-19), https://www.who.int/emergencies/dieases/novel-coronavirus-2019/questions-andanswers-hub/q-a-detail/q-a-coronaviruses. Retrieved 30/09/2020. 